\title{
Pengaruh Metode Penanaman Lingkar Berjajar Pada Pertumbuhan Tanaman Jagung Manis (Zea Mays Saccharata).
}

\section{Effect of Row Circle Planting Method On Growth of Sweet Corn}

\author{
Lutfy Ditya Cahyanti ${ }^{1^{*}}$ dan Use Etica ${ }^{2}$ \\ ${ }^{1,2}$ University of Darussalam Gontor \\ *E-mail : lutfyditya@unida.gontor.ac.id
}

\begin{abstract}
The experiment aims to know the effect of The off-row circle planting method on the growth of sweet corn. This research was conducted in the Sub District of Siman, Ponorogo, with altitude 140 asl and textured clay grumosol soil types. The research used a randomized block design (CBD) with 4 kinds of planting spaces included $C 1=8$ plant $/(60 \times 80) \mathrm{cm} 2, C 2$ $=16$ plant $/(60 \times 80) \mathrm{cm} 2, C 3=12$ plant $/(60 \times 80) \mathrm{cm} 2, C 4=1$ plant $/(60 \times 80) \mathrm{cm} 2, C 5=1$ plant/ $(60 \times 80) \mathrm{cm} 2$ with mowing. Each experimental unit was repeated 5 times so that there were 25 units. The observation was done at 21,28, 35, 42 and DAP (the day after planting). Some vegetative growth traits of sweet corn were determined as plant height $(\mathrm{cm})$, the number of leaves (leaf plant-1), leaf area $(\mathrm{m} 2)$ and leaf area index, fresh weight $(\mathrm{g})$ and dry weight $(g)$. Row circle planting method affected the fresh weight and dry weight of sweet on 49 DAP, sweet corn with 1 plant/ $(60 \times 80) \mathrm{cm} 2$ with mowing treatments showed the higher value and significantly different with other treatments, with $803 \mathrm{~g}$ for fresh weight and 7,70 g for dry weight.
\end{abstract}

Keywords: growth, planting, plant, row circle, sweet corn,

Disubmit : 27 Oktober 2019; Diterima : 17 November 2019; Disetujui : 10 Januari 2020

\section{PENDAHULUAN}

Jagung manis adalah komoditas tanaman pangan yang cukup dikenal dan disukai oleh masyarakat. Jagung manis dikonsumsi ketika bulir masih lunak dan segar sehingga bisa menjadi alternatif pangan, baik sebagai pelengkap sayur, jagung bakar, sirup bahkan sebagai pemanis pengganti gula tebu. Jagung manis dapat dipanen lebih awal, yaitu pada umur 80 hingga 90 hari setelah tanam, lebih awal 35 hingga 45 hari dibandingkan jagung biasa (Bhatt, 2012). Sekarang permintaan jagung manis telah meningkat pesat karena kandungan nutrisinya yang beragam dan rasanya yang enak, sehingga disukai berbagai kalangan dan menjadi faktor utama yang menyebabkan naiknya jumlah permintaan. Akan tetapi naiknya jumlah permintaan tersebut diikuti dengan jumlah produksi yang masih belum mencukupi. Faktor ini menyebabkan budidaya tanaman jagung manis dianggap sebagai usaha yang baik untuk bisnis pertanian apalagi dengan waktu panen yang lebih pendek di lapangan (Canatoy, 2018). Hal inilah yang mendorong munculnya teknologi-teknologi budidaya untuk terus meningkatkan hasil panen tanaman jagung manis. Salah satu upaya tersebut adalah dengan mengupayakan jarak tanam yang optimal untuk tanaman jagung manis. 
Jarak tanam merupakan faktor penting yang memiliki peranan dalam menentukan tingkat persaingan antar tanaman (Heitholt and Sassenrath-Cole, 2010). Jarak tanam yang optimum diharapkan akan membawa pada hasil tanaman yang optimal ketika semua persyaratan tumbuh sudah terpenuhi. Penggunaan jarak tanam yang tepat pada proses budidaya dilakukan untuk mengindari persaingan antar tanaman dalam menyerap air, unsur hara, dan cahaya matahari. Jarak tanam yang tepat untuk budidaya tanaman sangat penting untuk pemanfaatan cahaya matahari secara optimal untuk proses fotosintesis, sehingga dengan jarak tanam yang tepat, tanaman akan memperoleh ruang tumbuh yang seimbang (Ikhwani et al., 2013). Selain itu, pengaturan jarak tanam memiliki kegunaan untuk menghindari terjadinya penutupan antara tajuk tanaman, mengoptimalkan ruang untuk perkembangan akar dan tajuk tanaman, serta menghemat penggunaa benih. Pada tanah yang subur, seringkali diterapkan jarak tanam yang cenderung lebih lebar, sedangkan pada tanah yang kurang subur, jarak tanam yang digunakan cenderung lebih rapat (Muyassir, 2012). Dalam kegiatan budidaya, petani sering menggunakan jarak tanam yang tidak teratur sehingga akan meningkatkan potensi untuk terjadinya kompetisi baik terhadap air, unsur hara, maupun cahaya antar individu tanaman padahal jarak tanam menentukan populasi tanaman dalam suatu luasan tertentu sehingga pengaturan yang baik dapat mengurangi terjadinya kompetisi terhadap faktor-faktor tumbuh tersebut (Azis and Arman, 2013). Penggunaan jarak tanam harus dilakukan dengan ukuran yang tepat, tidak terlalu rapat ataupun tidak terlalu jarang. Jarak tanam yang terlalu lebar dapat berakibat kurang baik bagi pertumbuhan dan hasil tanaman, karena menimbulkan penguapan dan tingkat perkembangan gulma yang tinggi. Sebaliknya jarak tanam yang terlalu rapat mengakibatkan terjadinya kompetisi antar tanaman dalam mendapatkan cahaya matahari, unsur hara, dan air (Abdurrazak et al., 2013). Salah satu upaya pengaturan jarak tanam pada pertanaman jagung manis ialah dengan metode lingkar berjajar. Untuk itu, dilakukan penelitian ini bertujuan untuk mengetahui pengaruh metode penanaman lingkar berjajar pada pertumbuhan tanaman jagung manis.

\section{METODE PENELITIAN}

Peneltian ini telah dilaksanakan di kebun percobaan program studi Agroteknologi, Universitas Darussalam Gontor (Desa Siman Kabupatean Ponorogo) dengan ketinggian 140 dpl dan jenis tanah liat. Rancangan yang digunakan dalam peneltian ini adalah rancangan acak kelompok non factorial dengan perlakuan $\mathrm{C} 1=8 \operatorname{tanaman} /(60 x 80) \mathrm{cm} 2, \mathrm{C} 2=16 \operatorname{tanaman} /(60 \times 80) \mathrm{cm} 2, \mathrm{C} 3=12 \operatorname{tanaman} /(60 x 80) \mathrm{cm} 2, \mathrm{C} 4$ $=1 \operatorname{tanaman} /(60 \times 80) \mathrm{cm} 2, \mathrm{C} 5=1$ tanaman $/(60 \times 80) \mathrm{cm} 2$ dengan penyiangan, masing-masing perlakuan diulang 5 kali sehingga terdapat 25 unit petak percobaan. Pelaksanaan penelitian ini menggunakan bahanbahan berupa benih jagung manis yang ada di pasaran, sebagai perlakuan serta sarana produksi berupa pupuk urea/Za, Phonska dan pestisida. Alat yang digunakan dalam penelitian ini antara lain, cangkul, tugal, rol meter, sabit, hand sprayer oven,papan label serta alat tulis untuk pencatatan dalampengambilan data. Pengamatan dilakukan pada umur tanaman 21,28,35 dan 42 hst (hari setelah tanam). Parameter yang diamati adalah tinggi tanaman $(\mathrm{cm})$, jumlah daun (helai), luas daun $(\mathrm{cm} 2)$, bobot basah tanaman $(\mathrm{g})$ dan bobot kering tanaman $(\mathrm{g})$.

\section{HASIL DAN PEMBAHASAN}

Dari hasil pengamatan tinggi tanaman jagung manis yang tersaji pada Tabel 1, dapat diketahui bahwa tinggi tanaman jagung manis pada semua perlakuan mengalami peningkatan dari hari ke hari. Akan tetapi, tidak terdapat perbedaan yang siginifikan antara perlakuan satu dan perlakuan lainnya. 
Tabel 1. Rata-rata tinggi tanaman jagung manis (cm) pada pengamatan 21, 28, 35, 42 dan 49 HST akibat perlakuan lingkar tanam berjajar

Perlakuan Tinggi tanaman $(\mathrm{cm})$

\begin{tabular}{cccccc}
\hline & 21 & 28 & 35 & 42 & 49 \\
$\mathrm{C}_{1}$ & $46,00^{\text {tn }}$ & $82,07^{\text {tn }}$ & $119,20^{\text {tn }}$ & $154,50^{\text {tn }}$ & $194,60^{\text {tn }}$ \\
$\mathrm{C}_{2}$ & $50,75^{\text {tn }}$ & $87,60^{\text {tn }}$ & $116,30^{\text {tn }}$ & $160,80^{\text {tn }}$ & $188,90^{\text {tn }}$ \\
$\mathrm{C}_{3}$ & $50,55^{\text {tn }}$ & $87,10^{\text {tn }}$ & $118,40^{\text {tn }}$ & $161,10^{\text {tn }}$ & $189,80^{\text {tn }}$ \\
$\mathrm{C}_{4}$ & $46,05^{\text {tn }}$ & $82,40^{\text {tn }}$ & $113,80^{\text {tn }}$ & $147,80^{\text {tn }}$ & $184,40^{\text {tn }}$ \\
$C_{5}$ & $46,45^{\text {tn }}$ & $83,40^{\text {tn }}$ & $117,90^{\text {tn }}$ & $158,70^{\text {tn }}$ & $186,60^{\text {tn }}$ \\
\hline
\end{tabular}

Keterangan : $\mathrm{C}_{1}=8$ tanaman $/(60 \times 80) \mathrm{cm}^{2}, \mathrm{C}_{2}=16$ tanaman $/(60 \times 80) \mathrm{cm}^{2}, \mathrm{C}_{3}=12$ tanaman $/(60 \mathrm{x} 80) \mathrm{cm}^{2}$,

$\mathrm{C}_{4}=1$ tanaman $/(60 \times 80) \mathrm{cm}^{2}, \mathrm{C}_{5}=1$ tanaman $/(60 \times 80) \mathrm{cm}^{2}$ dengan penyiangan, $\mathrm{tn}=$ tidak berbeda nyata pada tingkat kepercayaan $5 \%$

Dari tabel di atas, terlihat bahwa pada pengamatan 49 hst, tanaman dengan perlakuan $\mathrm{C}_{1}, 8$ tanaman/(60x80) $\mathrm{cm}^{2}$ menghasilkan tinggi tanaman yang paling tinggi dibandingkan dengan perlakuan lainnya. Tinggi tanaman ialah indikator pertumbuhan tanaman yang sering digunakan untuk mengukur pengaruh lingkungan atau perlakuan yang diterapkan pada suatu tanaman. Sebagai parameter pengukur pengaruh lingkungan, tinggi tanaman sensitif terhadap faktor lingkungan seperti cahaya dan air. Sedangkan perlakuan $\mathrm{C}_{4}, 1$ tanaman/(60x80) $\mathrm{cm}^{2}$ menghasilkan tinggi tanaman yang paling rendah. Hal ini akibat terjadinya persaingan antara jagung manis dengan gulma yang ada dipertanaman akibat jarak tanam yang lebar. Kebutuhan pokok dari suatu tanaman untuk bisa melakukan proses fotosintesis diantaranya adalah cahaya, air, unsur hara, oksigen dan karbon dioksida. Interaksi tanaman dalam bentuk persaingan terjadi jika faktor tumbuh tersebut berada di lingkungan tumbuh dalam jumlah yang lebih sedikit. Secara rinci rata-rata tinggi tanaman jagung manis dapat dilihat pada Gambar 1 berikut.

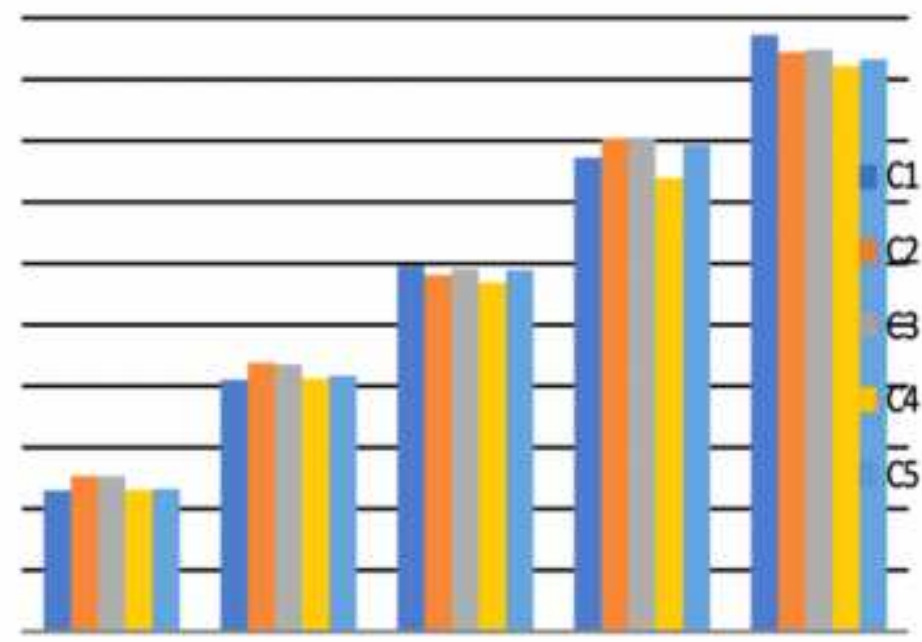

Gambar 1. Grafik rata-rata tinggi tanaman jagung manis $(\mathrm{cm})$ pada pengamatan 21, 28, 35, 42 dan 49 HST akibat perlakuan lingkar tanam berjajar

Dari Tabel 2 dibawah ini, dapat diketahui bahwa berdasarkan pengamatan pada tanaman jagung manis tidak berbeda nyata pada masing-masing perlakuan metode lingkar tanaman. Tetapi jumlah daun pada semua perlakuan mengalami peningkatan dari pengamatan 21 hst sampai dengan 49 hst. 
Tabel 2. Rata-rata jumlah daun tanaman jagung manis (helai) pada pengamatan 21, 28, 35, 42 dan 49 HST akibat perlakuan lingkar tanam berjajar

\begin{tabular}{|c|c|c|c|c|c|}
\hline \multirow[t]{2}{*}{ Perlakuan } & \multicolumn{5}{|c|}{ Jumlah Daun } \\
\hline & 21 & 28 & 35 & 42 & 49 \\
\hline $\mathrm{C}_{1}$ & $4,60^{\operatorname{tn}}$ & $5,30^{\mathrm{tn}}$ & $5,50^{\operatorname{tn}}$ & $5,50^{\operatorname{tn}}$ & $7,50^{\operatorname{tn}}$ \\
\hline $\mathrm{C}_{2}$ & $4,70^{\operatorname{tn}}$ & $5,00^{\text {tn }}$ & $5,10^{\operatorname{tn}}$ & $5,10^{\operatorname{tn}}$ & $7,90^{\operatorname{tn}}$ \\
\hline $\mathrm{C}_{3}$ & $4,50^{\mathrm{tn}}$ & $5,10^{\mathrm{tn}}$ & $5,20^{\mathrm{tn}}$ & $5,30^{\text {tn }}$ & $6,90^{\operatorname{tn}}$ \\
\hline $\mathrm{C}_{4}$ & $4,70^{\operatorname{tn}}$ & $5,00^{\mathrm{tn}}$ & $5,50^{\operatorname{tn}}$ & $5,50^{\mathrm{tn}}$ & $6,00^{\mathrm{tn}}$ \\
\hline $\mathrm{C}_{5}$ & $4,50^{\operatorname{tn}}$ & $5,40^{\text {tn }}$ & $5,50^{\text {tn }}$ & $5,90^{\operatorname{tn}}$ & $7,80^{\operatorname{tn}}$ \\
\hline
\end{tabular}

Dari hasil pengamatan luas daun pada umur 28, 35 dan 42 hst yang tersaji pada tabel 3 , terlihat bahwa luas daun pada tanaman jagung manis mengalami peningkatan dari hari ke hari. Dengan peningkatan luas daun artinya akan meningkatkan penyerapan cahaya oleh daun, kemudian proses fotosintesis akan meningkat dan menghasilkan asimilat yang akan digunakan sebagai sumber energi pertumbuhan dalam membentuk organ-organ vegetatif pada fase pertumbuhan, sedangkan pada fase generatif asimilat yang disimpan pada jaringan organ-organ vegetatif akan ditransfer untuk pembentukan organ reproduktif, seperti pengisian biji (Board and Kahlon, 2012). Luas daun berpengaruh pada radiasi matahari yang ditangkap, sedangkan kandungan klorofil pada tanaman yang mempunyai hijau daun merupakan energi dalam proses fotosintesis sehingga peningkatan luas daun akan diikuti dengan peningkatan cahaya matahari yang diserap oleh tanaman. Hal ini sesuai dengan pernyataan Jumin (2008) bahwa unsur cahaya matahari mempengaruhi pertumbuhan tanaman dan tertuju pada pertumbuhan vegetatif dan generatif. Respon tanaman terhadap cahaya ditentukan oleh sintesis hijau daun, kegiatan stomata (respirasi, transpirasi), pembentukan antosianin, suhu dari organ-organ permukaan, penyerapan hara mineral, permeabilitas, laju pernafasan, dan aliran protoplasma. Secara teoritis, semakin besar jumlah energi yang tersedia akan memperbesar jumlah hasil fotosintesis. Secara rinci dapat dilihat pada tabel 3 berikut.

Tabel 3. Rata-rata luas daun tanaman jagung manis $\left(\mathrm{cm}^{2}\right)$ pada pengamatan 28,35 dan 42 HST akibat perlakuan lingkar tanam berjajar

\begin{tabular}{crcc}
\hline Perlakuan & \multicolumn{3}{c}{ Luas daun tanaman $\left(\mathrm{cm}^{2}\right)$} \\
\hline $\mathrm{C}_{1}$ & $28 \mathrm{HST}$ & $35 \mathrm{HST}$ & $42 \mathrm{HST}$ \\
$\mathrm{C}_{2}$ & $484,59^{\text {tn }}$ & $1024,00^{\text {tn }}$ & $1690,00^{\text {tn }}$ \\
$\mathrm{C}_{3}$ & $585,5^{\text {tn }}$ & $965,00^{\text {tn }}$ & $1585,00^{\text {tn }}$ \\
$\mathrm{C}_{4}$ & $530,58^{\text {tn }}$ & $970,00^{\text {tn }}$ & $1562,00^{\text {tn }}$ \\
$\mathrm{C}_{5}$ & $479,78^{\text {tn }}$ & $828,00^{\text {tn }}$ & $1438,00^{\text {tn }}$ \\
\hline
\end{tabular}

Keterangan : $\mathrm{C}_{1}=8 \operatorname{tanaman} /(60 \times 80) \mathrm{cm}^{2}, \mathrm{C}_{2}=16 \operatorname{tanaman} /(60 \times 80) \mathrm{cm}^{2}, \mathrm{C}_{3}=12 \operatorname{tanaman} /(60 \mathrm{x} 80) \mathrm{cm}^{2}, \mathrm{C}_{4}=1$ tanaman/(60x80) $\mathrm{cm}^{2}, \mathrm{C}_{5}=1$ tanaman/(60x80) $\mathrm{cm}^{2}$ dengan penyiangan, $\mathrm{tn}=$ tidak berbeda nyata pada tingkat kepercayaan $5 \%$

Dari grafik pada Gambar 2 berikut, terlihat bahwa luas daun tanaman jagung manis yang paling luas dihasilkan pada perlakuan $\mathrm{C}_{1}, 8$ tanaman/(60x80) $\mathrm{cm}^{2}$. Peningkatan luas daun total tanaman dipengaruhi oleh perubahan jumlah dan ukuran masing-masing helai daun (Sektiwi et al., 2013). Effendi (2004) menyatakan bahwa luas daun juga berkorelasi dengan jumlah fotosintat yang dihasilkan oleh tanaman dari hasil 
fotosintesis. Semakin besar fotosintat yang dihasilkan oleh tanaman maka semakin besar pula hasil fotosintat yang ditranslokasikan ke bagian tanaman yang lain. Peluasan permukaan daun berhubungan dengan peningkatan jumlah dan ukuran kloroplas serta jumlah klorofil yang terdapat pada palisade dan spons parenkim. Susunan sel-sel jaringan palisade saling melekat, tetapi beberapa bagian terpisah sehingga udara dalam ruang antar sel tetap mencapai sisi panjang dengan kloroplas melekat tepi dinding. Hal ini berguna untuk efisiensi fotosintesis atau dimensi daerah permukaan bebas. Selain itu, adanya tulang-tulang daun kecil atau minor berfungsi dalam penyebaran arus transpirasi melalui mesofil dan berperan sebagai titik awal penyerapan hasil fotosintesis dan translokasinya ke luar daun. Sel penengah (sel antara mesofil dan unsure tapis) dalam tulang daun minor sesuai dengan konsep bahwa sel mentransportasikan karbohidrat ke aliran (konduit) dalam floem memerlukan energi, yang dipergunakan untuk dipakai dalam pertumbuhan dan penyimpanan (Lakitan,2001).

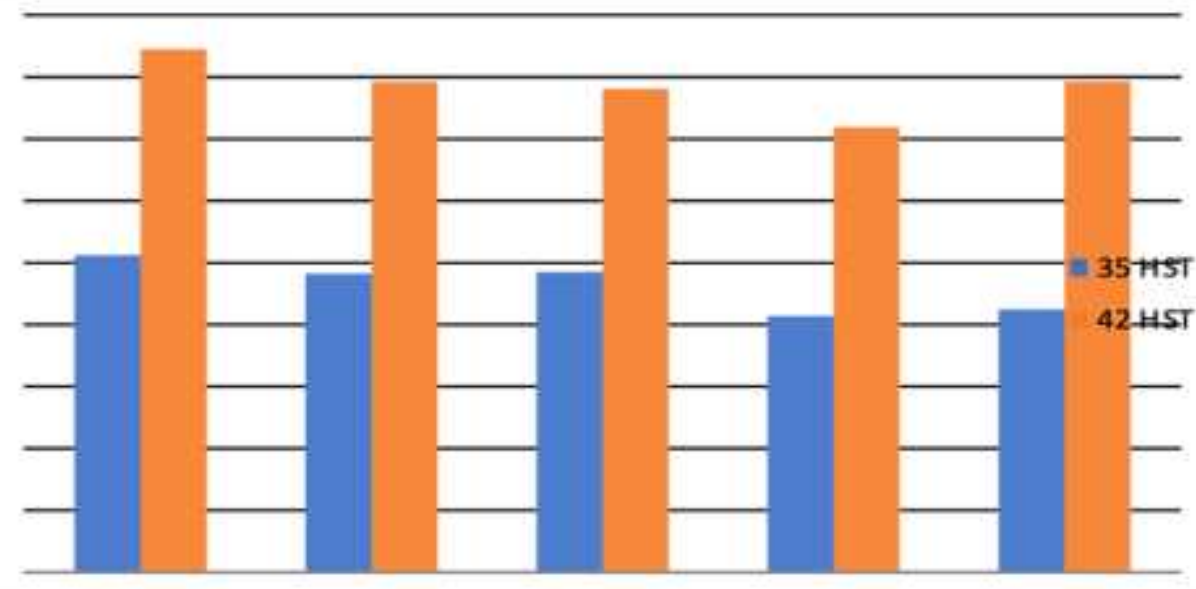

Gambar 2. Grafik rata-rata luas daun tanaman jagung manis $\left(\mathrm{cm}^{2}\right)$ pada pengamatan $21,28,35,42$ dan 49 HST akibat perlakuan lingkar tanam berjajar

Tabel hasil pengamatan luas area indeks daun tanaman jagung manis yang tersaji pada Tabel 4 menunjukkan bahwa LAI mengalami kenaikan dari umur pengamatan 28 HST sampai dengan umur 42 HST. Dalam pemodelan pertumbuhan tanaman, indeks luas daun (ILD) atau Luas Area Indeks (LAI) ialah parameter penting yang digunakan untuk menduga atau menghitung pembentukan biomassa tanaman. ILD adalah variabel yang digunakan untuk menyatakan kondisi daun tanaman yang berkaitan dengan proses biofisik tanaman, terutama dalam hubungannya dengan penyerapan radiasi matahari pada proses fotosintesis (Gusmayanti dan Sholahuddin, 2015).

Tabel 4. Luas Area Indeks (LAI) daun tanaman jagung manis pada pengamatan 28, 35 dan 42 HST akibat perlakuan lingkar tanam berjajar

Perlakuan Luas Area Indeks

\begin{tabular}{lccc}
\hline & 28 HST & 35 HST & $42 \mathrm{HST}$ \\
$\mathrm{C}_{1}$ & $0,10^{\text {tn }}$ & $0,21^{\text {tn }}$ & $0,34^{\text {tn }}$ \\
$\mathrm{C}_{2}$ & $0,12^{\text {tn }}$ & $0,19^{\text {tn }}$ & $0,32^{\text {tn }}$ \\
$\mathrm{C}_{3}$ & $0,11^{\text {tn }}$ & $0,19^{\text {tn }}$ & $0,32^{\text {tn }}$ \\
$\mathrm{C}_{4}$ & $0,09^{\text {tn }}$ & $0,16^{\text {tn }}$ & $0,29^{\text {tn }}$ \\
$\mathrm{C}_{5}$ & $0,08^{\text {tn }}$ & $0,17^{\text {tn }}$ & $0,32^{\text {tn }}$ \\
\hline
\end{tabular}

Keterangan : $\mathrm{C}_{1}=8 \operatorname{tanaman} /(60 \times 80) \mathrm{cm}^{2}, \mathrm{C}_{2}=16 \operatorname{tanaman} /(60 \times 80) \mathrm{cm}^{2}, \mathrm{C}_{3}=12 \operatorname{tanaman} /(60 \times 80) \mathrm{cm}^{2}, \mathrm{C}_{4}=1$ tanaman $/(60 \times 80) \mathrm{cm}^{2}, \mathrm{C}_{5}=1$ tanaman $/(60 \times 80) \mathrm{cm}^{2}$ dengan penyiangan, $\mathrm{tn}=$ tidak berbeda nyata pada tingkat kepercayaan $5 \%$ 
Dari Tabel 5 berikut, dapat diketahui bahwa terjadi kenaikan bobot basah pada masing perlakuan jagung manis dari hari ke hari. Pada pengamatan 21 hst sampai dengan pengamatan 42 hst tidak ada perbedaan yang nyata pada bobot basah tanaman jagung manis dari semua perlakuan. Sedangkan dari pengamatan 49 hst, dapat diketahu perbedaan yang nyata dari masing-masing perlakuan dimana hasil bobot basah tertinggi adalah pada perlakuan 1 tanaman/(60 x 80) $\mathrm{cm}^{2}$ dengan penyiangan yaitu 803 gram, yang berbeda nyata dengan perlakuan 1 tanaman/(60 x 80) $\mathrm{cm}^{2}$ dan 8 tanaman/(60x80) $\mathrm{cm}^{2}$. Pertambahan bobot basah tanaman berhubungan dengan pertambahan tinggi tanaman, jumlah daun dan luas daun. Pertambahan jumlah daun dan luas daun akan meningkatkan laju fotosintesis. Hasil dari proses fotosintes akan digunakan untuk partumbuhan organ-organ tanaman, baik organ vegetatif ataupun organ generatif anaman, dimana semakin besar organ tanaman yang terbentuk maka semakin banyak kadar air yang dapat diikat oleh tanaman (Koryati, 2004). Selain itu, dengan peningkatan tinggi tanaman dan luas daun, akan meningkatkan bobot basah tanaman. Hal ini sependapat dengan Prasetya (2009) yang menyebutkan bahwa bobot basah tanaman dipengaruhi oleh tinggi tanaman dan luas daun, semakin tinggi dan semakin besar luas daunnya maka bobot segar tanaman akan semakin tinggi

Tabel 5. Rata-rata bobot basah tanaman jagung manis (gram) pada pengamatan 21, 28, 35, 42 dan 49 HST akibat perlakuan lingkar tanam berjajar

\begin{tabular}{cccccc}
\hline Perlakuan & \multicolumn{5}{c}{ Bobot basah (gram) } \\
\hline $\mathrm{C}_{1}$ & 21 & 28 & 35 & 42 & 49 \\
$\mathrm{C}_{2}$ & $13^{\text {tn }}$ & $49^{\text {tn }}$ & $142^{\text {tn }}$ & $385^{\text {tn }}$ & $682^{\text {ab }}$ \\
$\mathrm{C}_{3}$ & $16^{\text {tn }}$ & $50^{\text {tn }}$ & $178^{\text {tn }}$ & $366^{\text {tn }}$ & $726^{\text {bc }}$ \\
$C_{4}$ & $17^{\text {tn }}$ & $62^{\text {tn }}$ & $191^{\text {tn }}$ & $448^{\text {tn }}$ & $721^{\text {bc }}$ \\
$C_{5}$ & $14^{\text {tn }}$ & $55^{\text {tn }}$ & $124^{\text {tn }}$ & $466^{\text {th }}$ & $598^{\text {a }}$ \\
\hline
\end{tabular}

Keterangan : $\mathrm{C}_{1}=8 \operatorname{tanaman} /(60 \mathrm{x} 80) \mathrm{cm}^{2}, \mathrm{C}_{2}=16 \operatorname{tanaman} /(60 \mathrm{x} 80) \mathrm{cm}^{2}, \mathrm{C}_{3}=12 \operatorname{tanaman} /(60 \mathrm{x} 80) \mathrm{cm}^{2}, \mathrm{C}_{4}=1$ tanaman/(60x80) $\mathrm{cm}^{2}, \mathrm{C}_{5}=1$ tanaman/(60x80) $\mathrm{cm}^{2}$ dengan penyiangan, $\mathrm{tn}=$ tidak berbeda nyata pada tingkat kepercayaan $5 \%$

Tabel 6. Rata-rata bobot kering tanaman jagung manis (gram) pada pengamatan 21, 28, 35, 42 dan 49 HST akibat perlakuan lingkar tanam berjajar

\begin{tabular}{lccccc}
\hline \multicolumn{5}{c}{ Perlakuan } & \multicolumn{5}{c}{ Bobot kering (gram) } \\
\hline & 21 & 28 & 35 & 42 & 49 \\
$\mathrm{C}_{1}$ & $2,83^{\text {tn }}$ & $5,05^{\text {tn }}$ & $16,64^{\text {tn }}$ & $45,05^{\text {ab }}$ & $88,12^{\text {bc }}$ \\
$\mathrm{C}_{2}$ & $4,04^{\text {tn }}$ & $5,42^{\text {tn }}$ & $13,79^{\text {tn }}$ & $48,90^{\text {ab }}$ & $80,70^{\mathrm{b}}$ \\
$\mathrm{C}_{3}$ & $4,33^{\text {tn }}$ & $6,70^{\text {tn }}$ & $21,60^{\text {tn }}$ & $52,07^{\mathrm{bc}}$ & $85,61^{\mathrm{b}}$ \\
$\mathrm{C}_{4}$ & $4,14^{\text {tn }}$ & $5,87^{\text {tn }}$ & $12,37^{\text {tn }}$ & $42,56^{\mathrm{a}}$ & $67,36^{\mathrm{a}}$ \\
$\mathrm{C}_{5}$ & $5,04^{\text {tn }}$ & $6,04^{\text {tn }}$ & $15,67^{\text {tn }}$ & $53,94^{\mathrm{c}}$ & $97,70^{\mathrm{c}}$ \\
\hline
\end{tabular}

Keterangan : $\mathrm{C}_{1}=8 \operatorname{tanaman} /(60 \times 80) \mathrm{cm}^{2}, \mathrm{C}_{2}=16 \operatorname{tanaman} /(60 \times 80) \mathrm{cm}^{2}, \mathrm{C}_{3}=12 \operatorname{tanaman} /(60 \times 80) \mathrm{cm}^{2}, \mathrm{C}_{4}=1$ tanaman $/(60 \times 80) \mathrm{cm}^{2}, \mathrm{C}_{5}=1$ tanaman/(60x80) $\mathrm{cm}^{2}$ dengan penyiangan, $\mathrm{tn}=$ tidak berbeda nyata pada tingkat kepercayaan $5 \%$

Dari hasil pengamatan yang disajikan Tabel 6 di atas, terlihat bahwa tidak ada perbedaan yang nyata pada bobot kering tanaman jagung manis pada semua perlakuan dari pengamatan 21 hst-35 hst. Pada umur $42 \mathrm{hst}$, terlihat bahwa perlakuan 1 tanaman/(60x80) $\mathrm{cm}^{2}$ menghasilkan bobot kering yang rendah yaitu 42,56 gram, yang berbeda nyata dengan perlakuan 12 tanaman/(60x80) $\mathrm{cm}^{2}$ dengan bobot kering sebesar 52,07 gram dan perlakuan 1 tanaman/(60 x 80) $\mathrm{cm}^{2}$ dengan penyiangan dengan bobot kering sebesar 53,94 gram. Sedangkan pada umur pengamatan 49 hst, terlihat bahwa terlihat bahwa perlakuan 1 tanaman/(60x80) $\mathrm{cm}^{2}$ menghasilkan bobot kering yang paling rendah yaitu 67,36 gram, yang berbeda nyata dengan 4 perlakuan 
lainnya, yaitu 8 tanaman/(60x80) $\mathrm{cm}^{2}, 16 \operatorname{tanaman} /(60 x 80) \mathrm{cm}^{2}, 2 \operatorname{tanaman} /(60 x 80) \mathrm{cm}^{2}$ dan 1 tanaman/(60x $80) \mathrm{cm}^{2}$ dengan penyiangan. Sedangkan perlakuan 1 tanaman/(60x80) $\mathrm{cm}^{2}$ dengan penyiangan menghasilkan bobot kering yang tinggi, sebesar 97,70 gram tetapi tidak berbeda nyata dengan 8 tanaman/(60x80) $\mathrm{cm}^{2}$ sebesar 88,12 gram. Rendahnya hasil bobot kering tanaman jagung manis pada perlakuan 1 tanaman/(60x80) $\mathrm{cm}^{2}$ disebabkan karena perlakuan jarak tanam yang luas menyebabkan banyak ruang kosong yang akan ditumbuhi gulma. Tingginya kompetisi tanaman jagung manis dan gulma menyebabkan tanaman tidak dapat tumbuh dan berkembang secara optimal akibat terbatasnya faktor ruang tumbuh dan unsur hara. Sedangkan terbatasnya ruang tumbuh tanaman akan mengganggu proses perkembangan akar serta penyerapan unsur hara dan air (Dinata et al.,, 2017). Bahan berat kering tanaman ialah indikator efisiensi penyerapan unsur hara dari pemanfaatan radiasi matahari yang tersedia selama pertumbuhan oleh tajuk tanaman, dan daun merupakan organ utama penyerapan radiasi matahari tersebut. Menurut Lakitan (2012), pertumbuhan tanaman ditunjukkan dengan pertambahan ukuran dan berat kering tanaman yang dicerminkan dengan bertambahnya protoplasma yang terjadi karena bertambahnya ukuran sel.

\section{KESIMPULAN}

Metode tanam lingkar berjajar mempengaruhi bobot basah dan bobot kering tanaman jagung manis pada umur pengamatan 49 hst, dimana perlakuan dengan single row, atau 1 tanaman/(60x80) $\mathrm{cm}^{2}$ dengan penyiangan menghasilkan bobot basah dan bobot kering tanaman tertinggi dan berbeda nyata dibandingkan dengan 4 perlakuan lainnya, masing-masing $803 \mathrm{~g}$ dan 97,70 gram.

\section{UCAPAN TERIMA KASIH}

Terimakasih kami ucapkan pada Dirjen Riset dan Pengembangan Kementrian Riset dan Pendidikan Tinggi yang telah mendanai penelitian ini melalui skema Penelitian Dosen Pemula.

\section{DAFTAR PUSTAKA}

Abdurrazak, Hatta, M. \& Marliah, A., 2013. Pertumbuhan dan Hasil Tanaman Mentimun (Cucumis Sativus L.) Akibat Perbedaan Jarak Tanam dan Jumlah Benih Per Lubang Tanam. Jurnal Agrista, 17(2), pp.. $55-59$.

Azis, A. \& Arman, 2013. Response of Planting Distance and Granul Organic. Jurnal Agrisistem, 9(1), pp.. $16-23$.

Bhatt, P. S., 2012. Response of sweet corn hybrid to varying plant densities and nitrogen levels. African Journal of Agricultural Research, 7(46), pp. 6158-6166.

Board, J. E. \& Kahlon, C. S., 2012. Contribution of Remobilized Total Dry Matter to Soybean Yield. Journal of Crop Improvement, 26, pp. 641-654.

Canatoy, R. C., 2018. Growth and yield response of sweet corn ( zea mays 1. Var . Saccharata ) as affected by tillage operations and fertilizer applications. International Journal of Educations and Research, 6(4), pp. 265-276.

Dinata, A., Sudiarso \& Sebayang, H. T., 2017. Pengaruh Waktu Dan Metode Pengendalian Gulma Terhadap Pertumbuhan dan Hasil Tanaman Jagung ( Zea Mays L .). Jurnal Produksi Tanaman, 5(2), pp. 191197.

Efendi, R., A.F. Fadhly, M. Akil, \& M. Rauf, 2004. Pengaruh Sistem Pengolahan Tanah dan Penyiangan Gulma Terhadap Pertumbuhan dan Hasil Jagung. Seminar Mingguan. Balai Penelitian Tanaman Serealia, Maros, 26 Maret 2004.17p.

Gusmayanti, E. \& Sholahuddin, 2015. Luas Daun Spesifik dan Indeks Luas Daun Tanaman Sagu di Desa Sungai Ambangah Kalimantan Barat. Prosiding Semirata 2015 bidang Teknologi Informasi dan Multi Disiplin (hlm. 184-192). 
Heitholt, J. J. \& Sassenrath-Cole, G. F., 2010. Inter-Plant Competition : Growth Responses to Plant Density and Row Spacing. In: Physiology of Cotton. pp. 179-186.

Ikhwani, Pratiwi, G. R., Paturrohman, E. \& Makarim, A.K., 2013. Peningkatan Produktivitas Padi Melalui Penerapan Jarak Tanam Jajar Legowo. Iptek Tanaman Pangan, 8(2), pp. 72-79.

Jumin, H. B., 2008. Dasar-Dasar Agronomi. Jakarta: PT Rajagrafindo Persada.

Koryati, T., 2004. Pengaruh Penggunaan Mulsa dan pemupukan Urea terhadap Pertumbuhan dan Produksi Cabai Merah ( Capsicum annum L .). Jurnal Penelitian Bidang Ilmu Pertanian, 2(1), pp. 13-16.

Lakitan. 2001. Dasar-dasar Fisiologi Tumbuhan. PT Raja Grafindo Persada.Jakarta.

Muyassir, 2012. Efek Jarak Tanam, Umur dan Jumlah Bibit Terhadap Hasil Padi Sawah (Oryza sativa L.). Jurnal Manajemen Sumberdaya Lahan, 1(2), pp. 207-212.

Prasetya, B., S. Kurniawan, \& M. Febrianingsih, 2009. Pengaruh Dosis dan Frekuensi Pupuk Cair Terhadap Serapan N dan Pertumbuhan Sawi (Brassica juncea L.) pada Entisol. Jurnal Agritek.17(5):1022-1029.

Sektiwi, A. T., Aini, N. \& Sebayang, H. T., 2013. Kajian model tanam dan waktu tanam dalam sistem tumpangsari terhadap pertumbuhan dan produksi benih jagung. Jurnal produksi tanaman, 1(3), pp. 59-70. 